\title{
Effect of Sb on the Properties of GalnP Top Cells
}

J.M. Olson, W.E. McMahon, and Sarah Kurtz

- Background

-Efficiency of GaInP/GaAs tandem cells:

effect of top cell band gap

-Why Sb?

-Result

-Properties of Sb:GaInP

-Sb:GaInP top cells

-Sb:GaInP/GaAs tandem cells

NREL/PR-520-39859

- Summary

Presented at the 2006 IEEE 4th World Conference on Photovoltaic Energy Conversion (WCPEC-4) held May 7-12, 2006 in Waikoloa, Hawaii. 


\section{Disclaimer and Government License}

This work has been authored by Midwest Research Institute (MRI) under Contract No. DE-AC36-99G010337 with the U.S. Department of Energy (the "DOE"). The United States Government (the "Government") retains and the publisher, by accepting the work for publication, acknowledges that the Government retains a non-exclusive, paid-up, irrevocable, worldwide license to publish or reproduce the published form of this work, or allow others to do so, for Government purposes.

Neither MRI, the DOE, the Government, nor any other agency thereof, nor any of their employees, makes any warranty, express or implied, or assumes any liability or responsibility for the accuracy, completeness, or usefulness of any information, apparatus, product, or process disclosed, or represents that its use would not infringe any privately owned rights. Reference herein to any specific commercial product, process, or service by trade name, trademark, manufacturer, or otherwise does not constitute or imply its endorsement, recommendation, or favoring by the Government or any agency thereof. The views and opinions of the authors and/or presenters expressed herein do not necessarily state or reflect those of MRI, the DOE, the Government, or any agency thereof. 


\section{A Bit of History}

- In 1984 - invention of GalnP/GaAs tandem cell. (Olson)

- In 1989 - 27.3\% (Olson et al.)

- In 1993 - 29.5\% (Bertness et al.)

n

p GaInP

Tunnel junction

n

p

GaAs

- In 1997 - 30.3\% AM1.5G

(Takamoto et al.) commercial GalnP/GaAs cell (Spectrolab, et al.)

- Space applications, Mars rovers

- Terrestrial concentrator applications

Substrate 


\section{GalnP/GaAs tandem cell}

- Ideal top cell band gap for a GaAs bottom cell is $\sim 1.9 \mathrm{eV}$ ( 2eV AM0).

- Typical band gap of GalnP is $\sim 1.8 \mathrm{eV}$ which reduces the ultimate efficiency by about 1 point.

\begin{tabular}{|lc|}
\hline $\mathbf{n}$ & \\
\hline $\mathbf{p}$ & GaInP \\
\hline & Tunnel junction \\
\hline $\mathbf{n}$ & \\
\hline $\mathbf{p}$ & \\
& GaAs \\
\end{tabular}




\section{Ordering in GalnP}

- Band gap shift

- caused by CuPt ordering of Ga and In on the Group III sublattice.

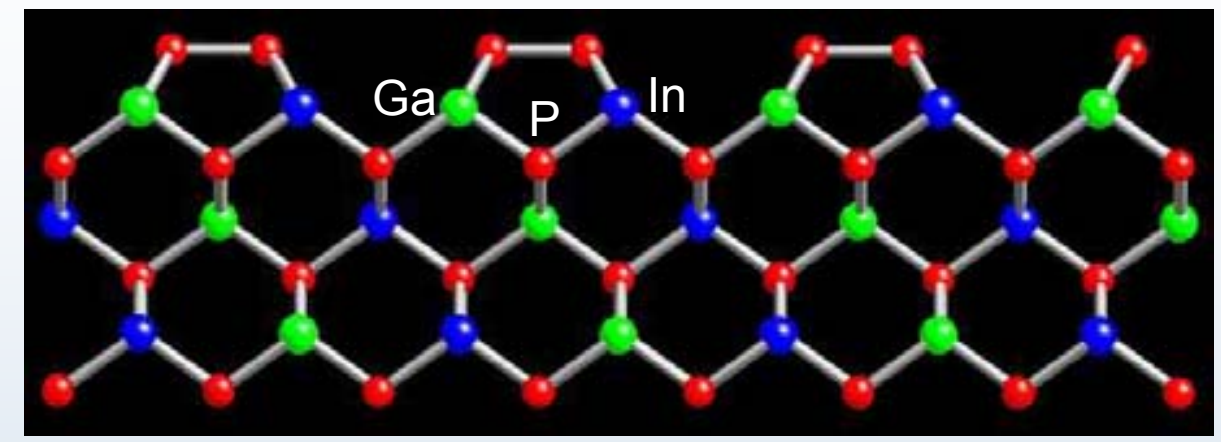

- Order parameter and band gap energy varies with

- growth temperature

- growth rate,

- $\mathrm{PH}_{3}$ partial pressure,

- substrate orientation

- Type and concentration of shallow dopants. (Kurtz el al. JEM 1994)

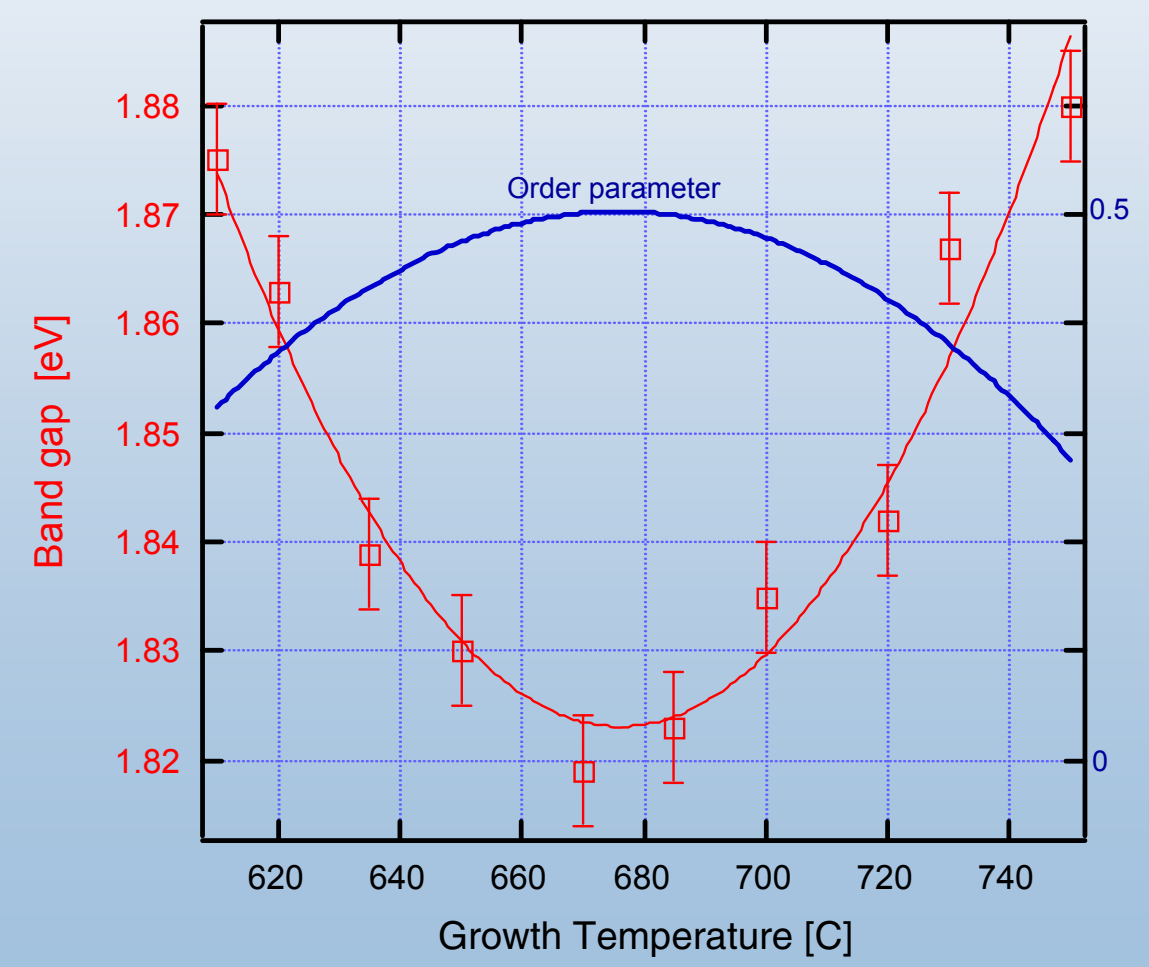




\section{Effect of Sb on the Bandgap of GalnP}

- Addition of Sb (TESb) during growth can hinder the ordering process and increase the band gap*

- Effect controlled by ratio of TESb to $\mathrm{PH}_{3}(\mathrm{Sb} / \mathrm{P})$

- Effect is largest for

- B-miscut substrates

- $\mathrm{Tg} \sim 625^{\circ} \mathrm{C}$

*Shurtleff et al. APL (1999)

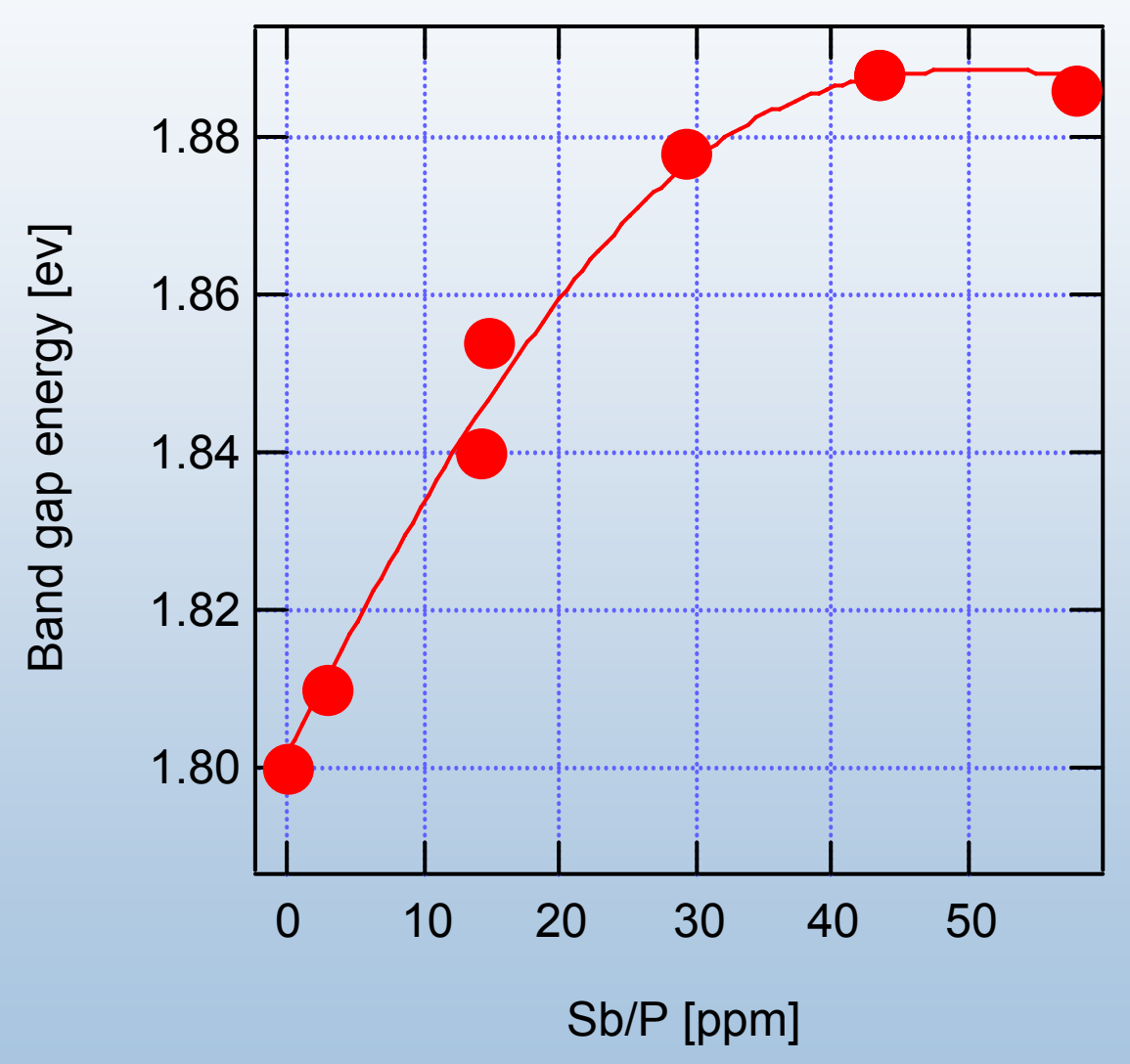




\section{Sb incorporation vs $\mathrm{Tg}$}

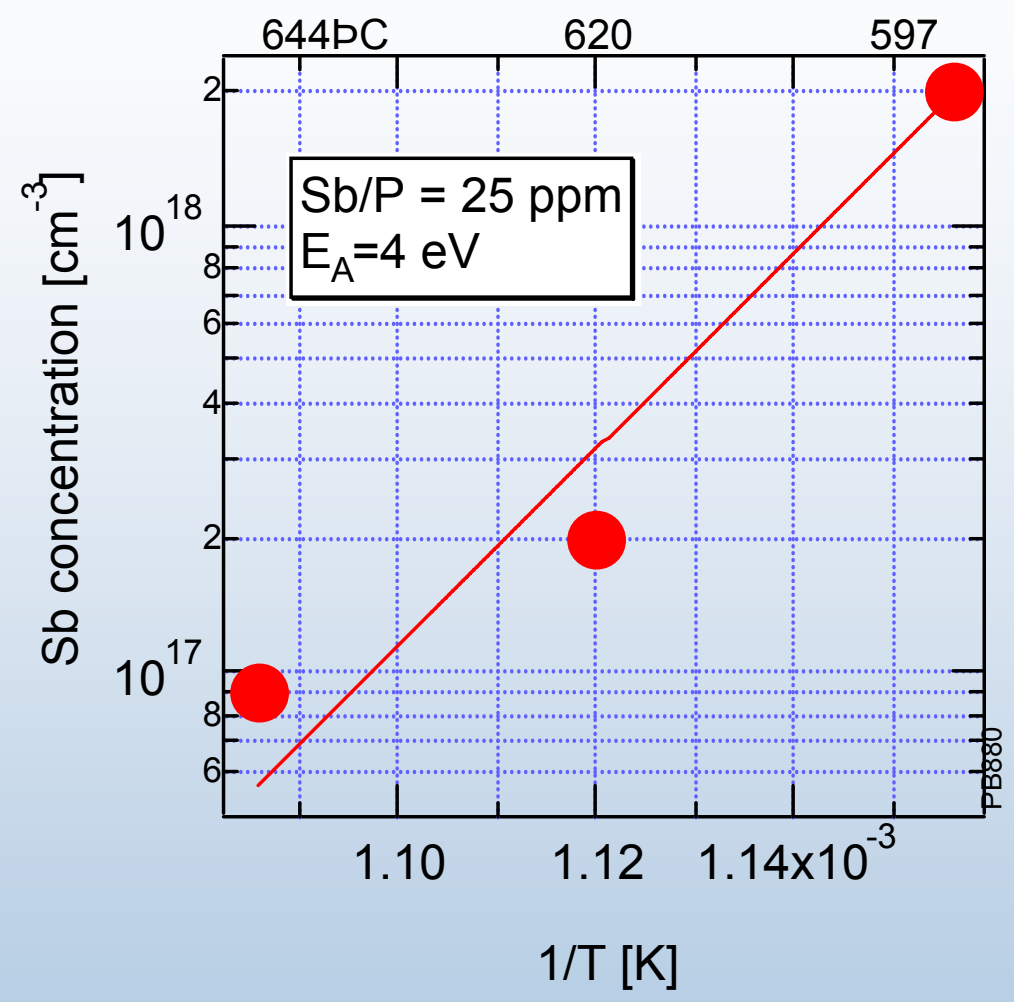

- Under conditions used for top cell, $\mathrm{C}_{\mathrm{Sb}}=\sim 2 \mathrm{e} 17 \mathrm{~cm}^{-3}$

- Activation energy $\sim 4 \mathrm{eV}$, comparable to that of the $1 / \mathrm{P}_{\mathrm{Sb}}$. 


\section{Surface Concentration $\Theta_{\mathrm{Sb}}$ on GalnP}

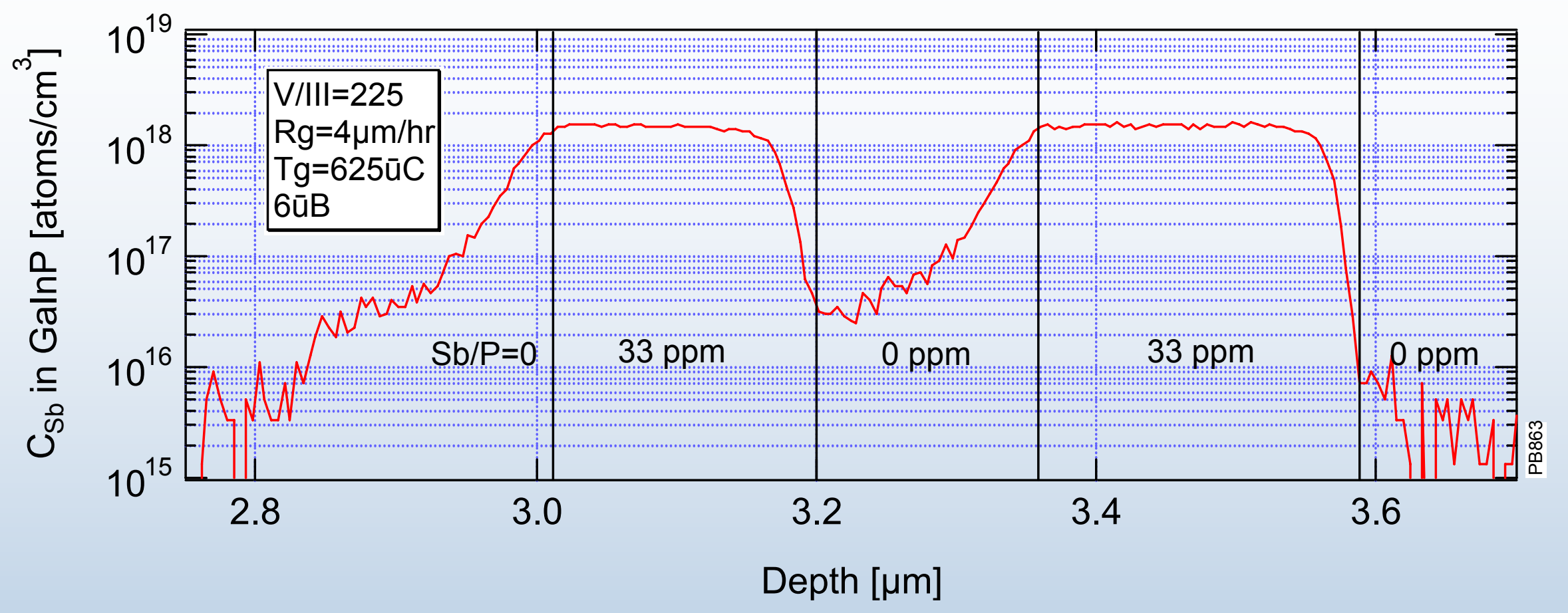

- The $1 /$ e decay length $L=23 n m$

- Surface segregation coefficient $R=\exp \left(-a_{0} / L\right)=0.988$

- Sb surface concentration $\theta_{\mathrm{Sb}} \propto \mathrm{C}_{\mathrm{Sb}} /(1-\mathrm{R}), \theta_{\mathrm{Sb}}=0.006$

- Implies (001) terrace not occupied with Sb-Sb dimers

- Theoretical work - preferred Sb attachment at B-type steps, (Batyrev, PRL 2005) 


\section{Ordered domain structure}
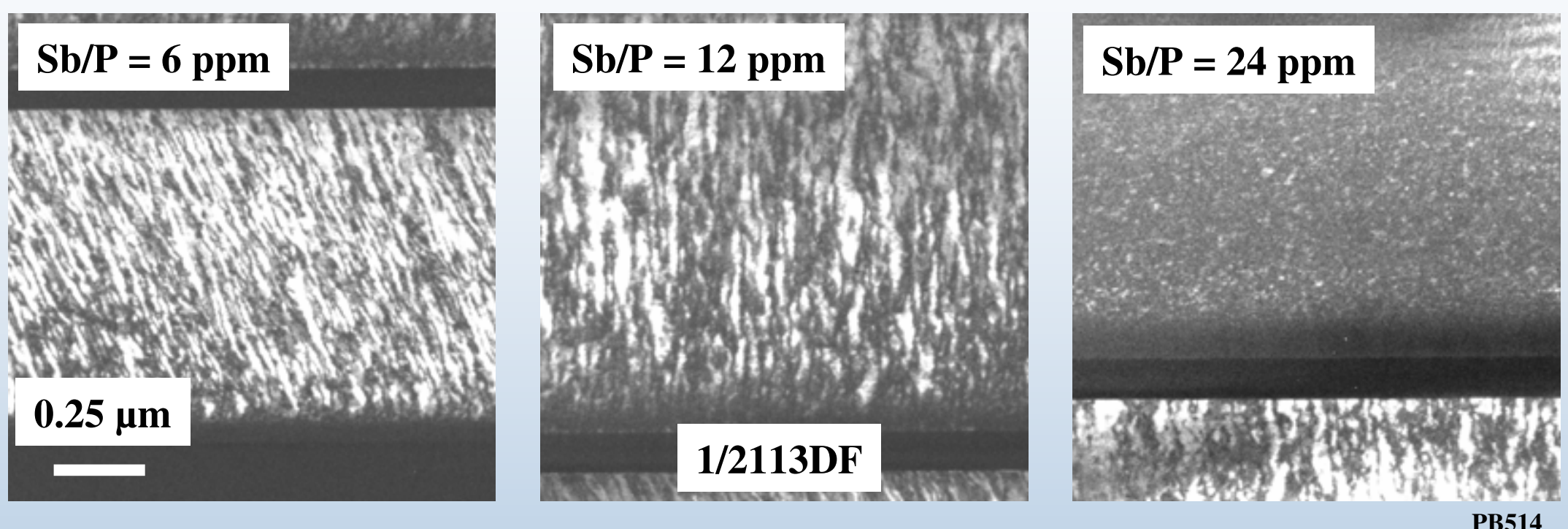

- Tilted domain boundaries result from step flow (Ishimura, et al PRB 51 p9707) 


\section{Surface morphologies of Sb:GalnP on singular GaAs(100)}

- For intermediate Sb, surface composed of asymmetric hillocks, 5 to $7 \mathrm{~nm}$ high, bounded by low angle B-type facets, Friedman et al APL (1993).
- For higher Sb, surface composed of large terraces separated by ML steps $(0.28 \mathrm{~nm})$.

- This implies that Sb raises the energy of Btype steps on GalnP(100).
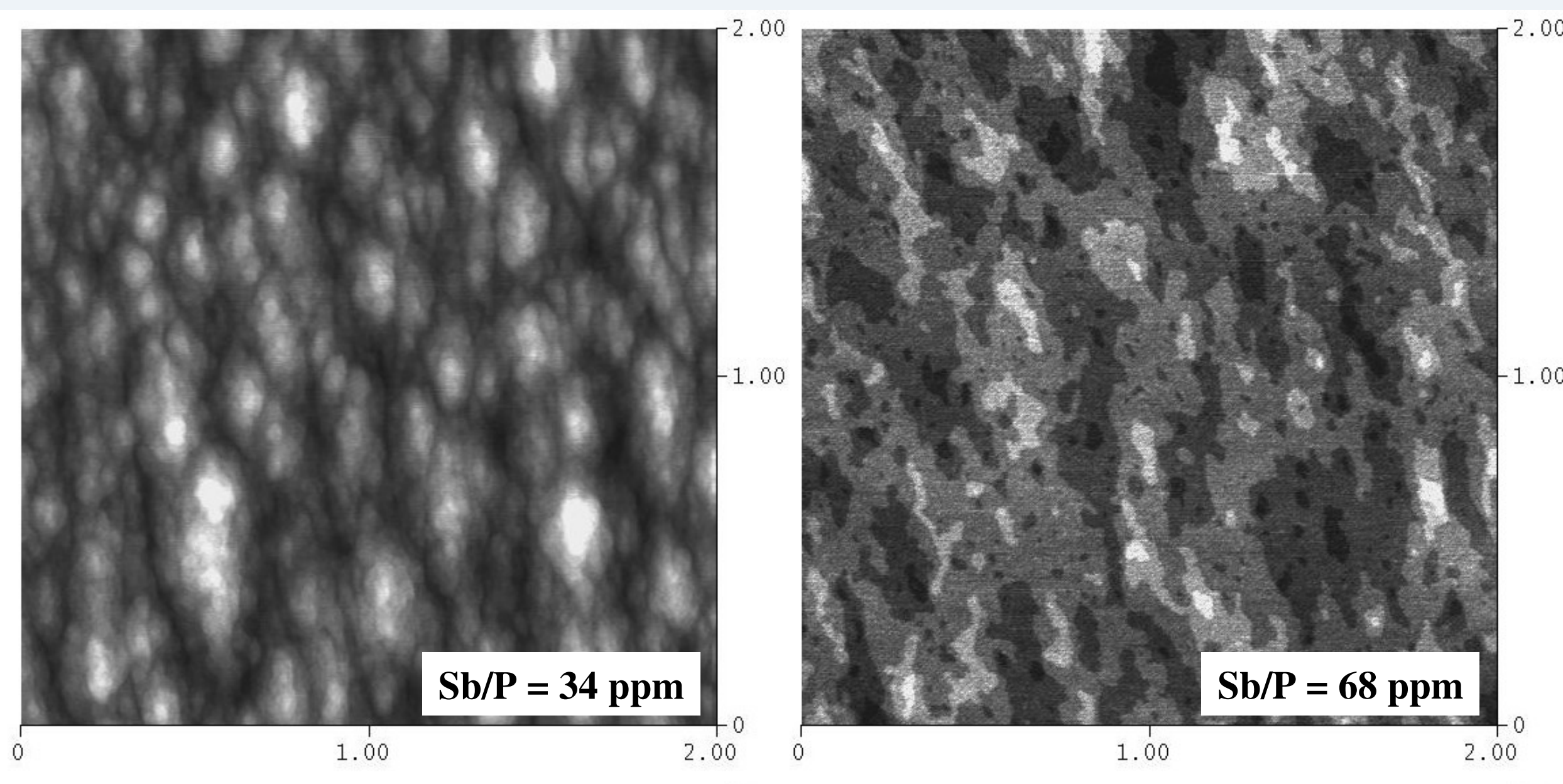


\section{Effect of Sb on Se incorporation}

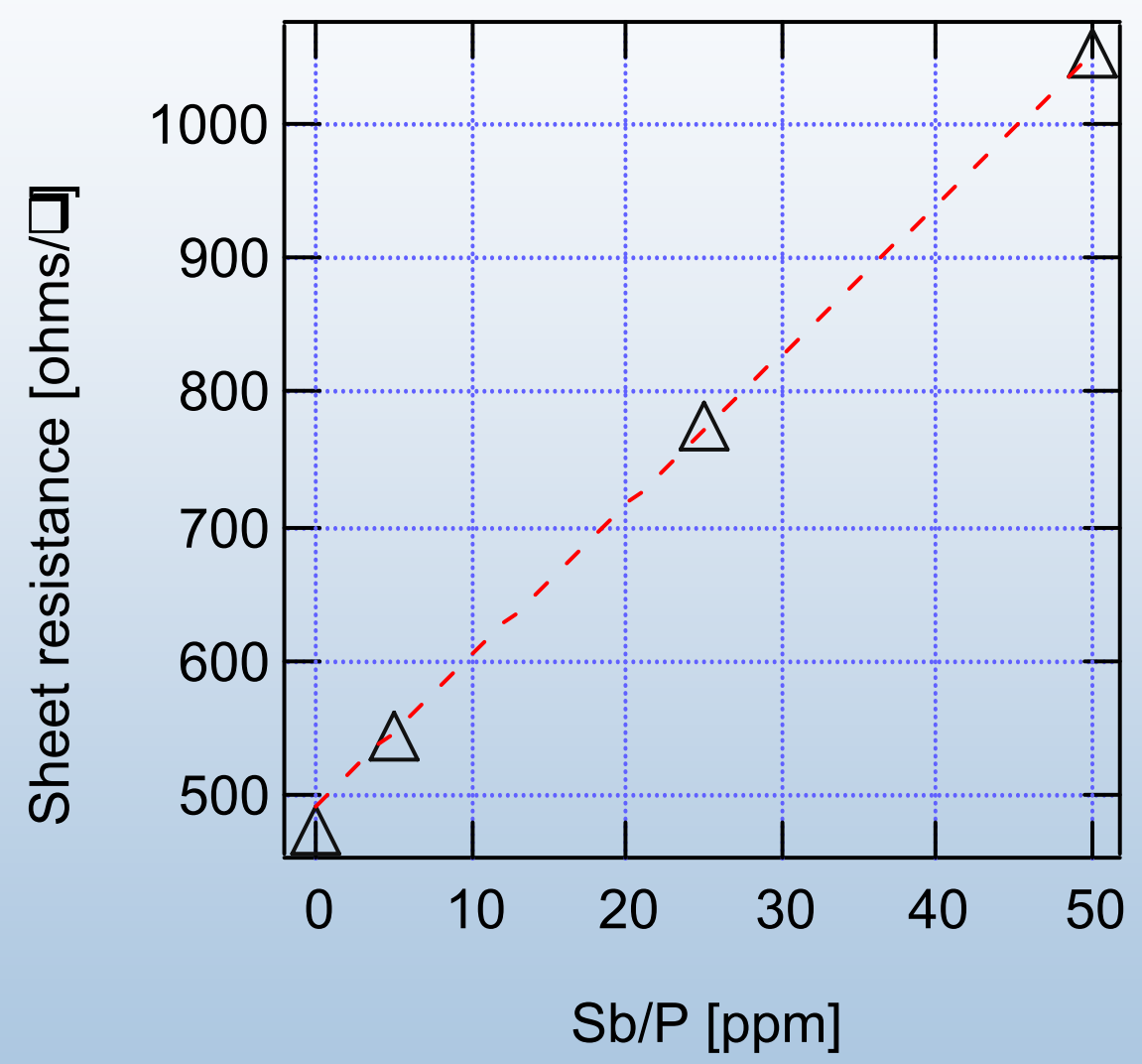

- Sb, P and Se compete for group V lattice sites

- $\mathrm{C}_{\mathrm{Se}} \propto \alpha \mathrm{F}_{\mathrm{Se}} /\left(1+\alpha \mathrm{F}_{\mathrm{Se}}+\beta \mathrm{F}_{\mathrm{Sb}}+\gamma \mathrm{F}_{\mathrm{P}}\right)$ 


\section{Effect of Sb on Group III Site Occupations}
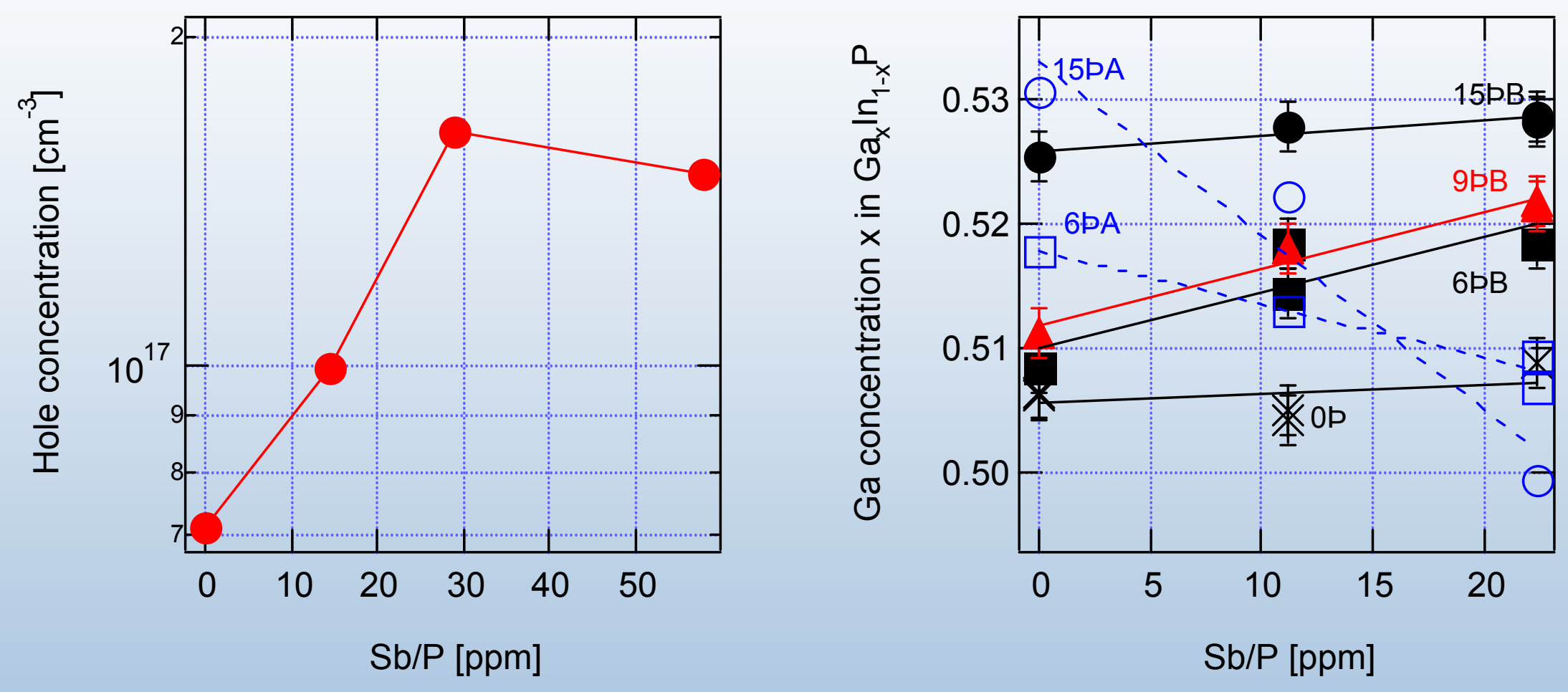

Mechanism? 


\section{Sb-doped GalnP top cells}
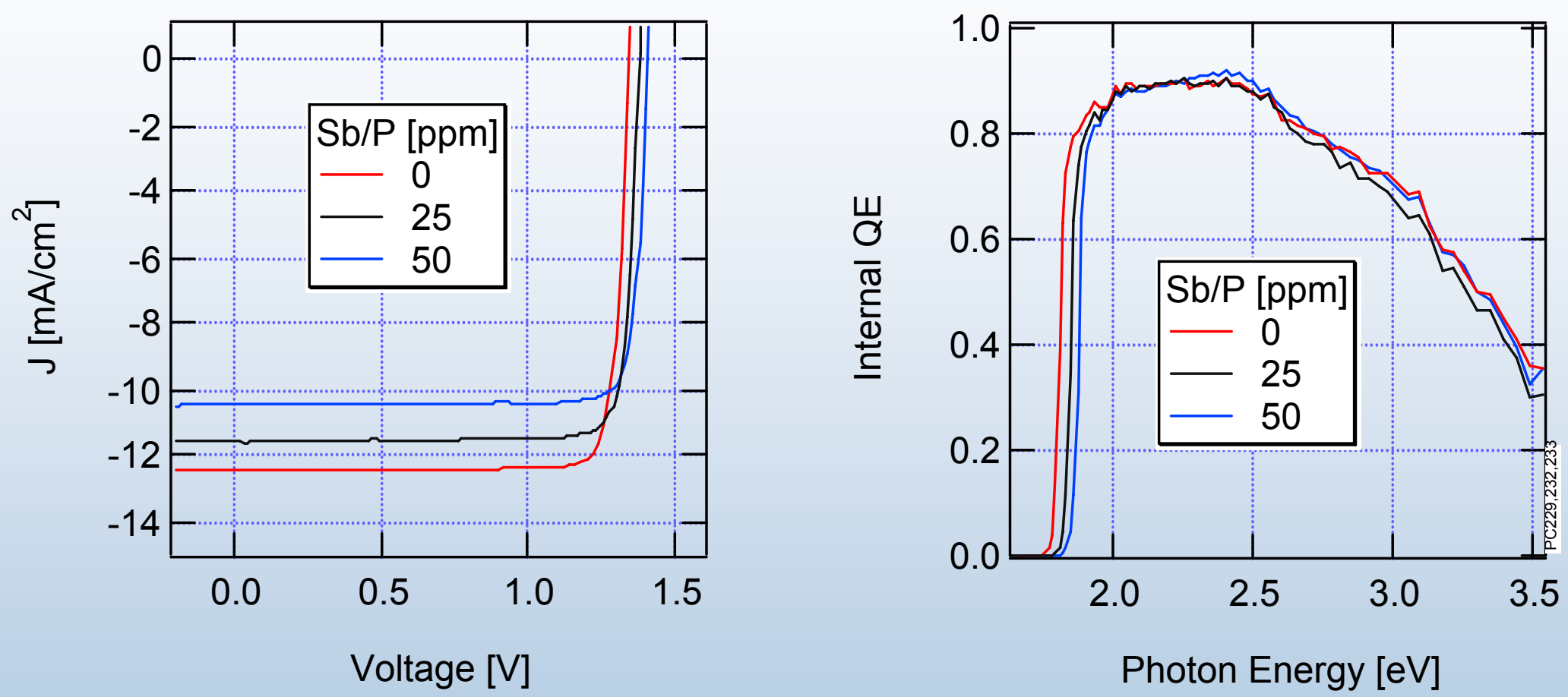

- The base/emitter/window thicknesses are $2 \mu \mathrm{m}, 0.1 \mu \mathrm{m}$ and $0.025 \mu \mathrm{m}$, respectively

- The base $p$ varies from $7 \mathrm{e} 16$ to $\sim 2 \mathrm{e} 17 \mathrm{~cm}^{-3}$

- The emitter sheet resistance varies from 500 to $1000 \Omega / \square$. 


\section{Top cell device parameters vs Sb}
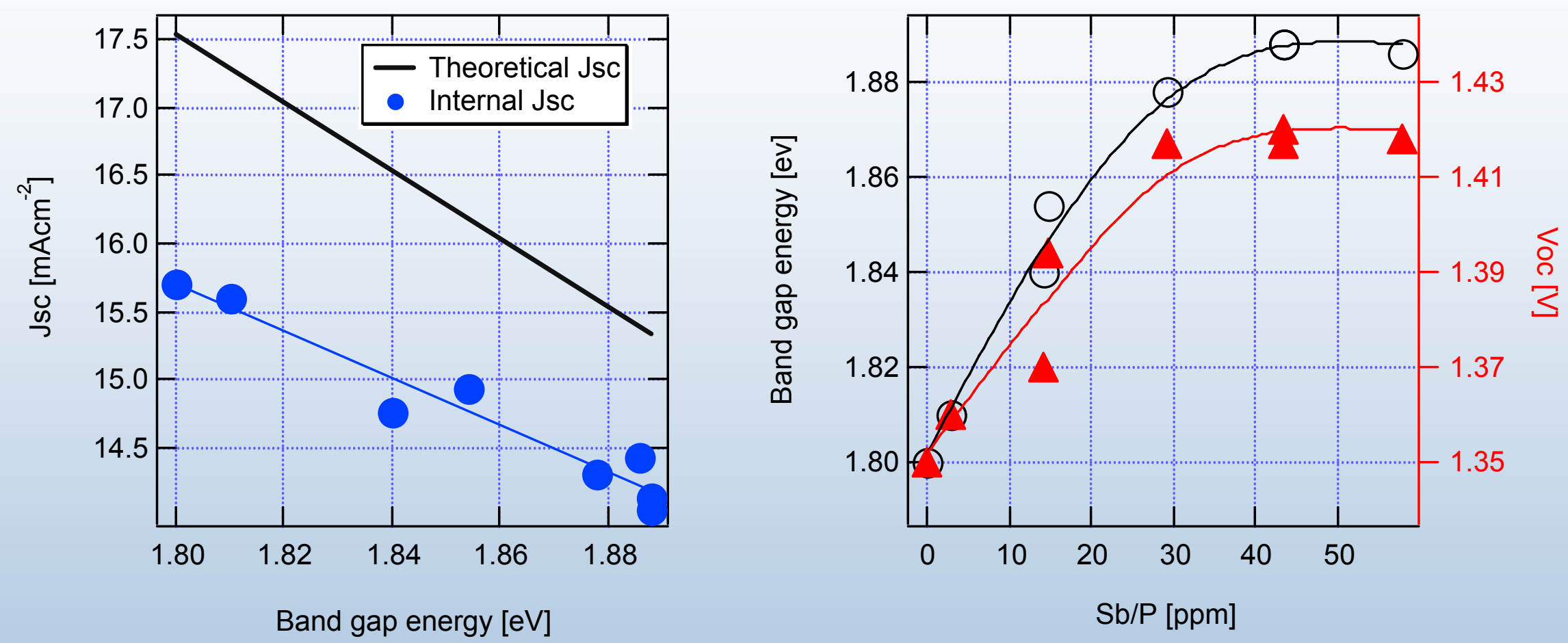

- Internal $\mathrm{J}_{\mathrm{sc}}$ decreases with $\mathrm{E}_{\mathrm{g}}$ slower than expected.

- $\mathrm{V}_{\text {oc }}$ increases more slowly than $\mathrm{E}_{\mathrm{g}}$. 


\section{Sb-doped GalnP/GaAs tandem cells}

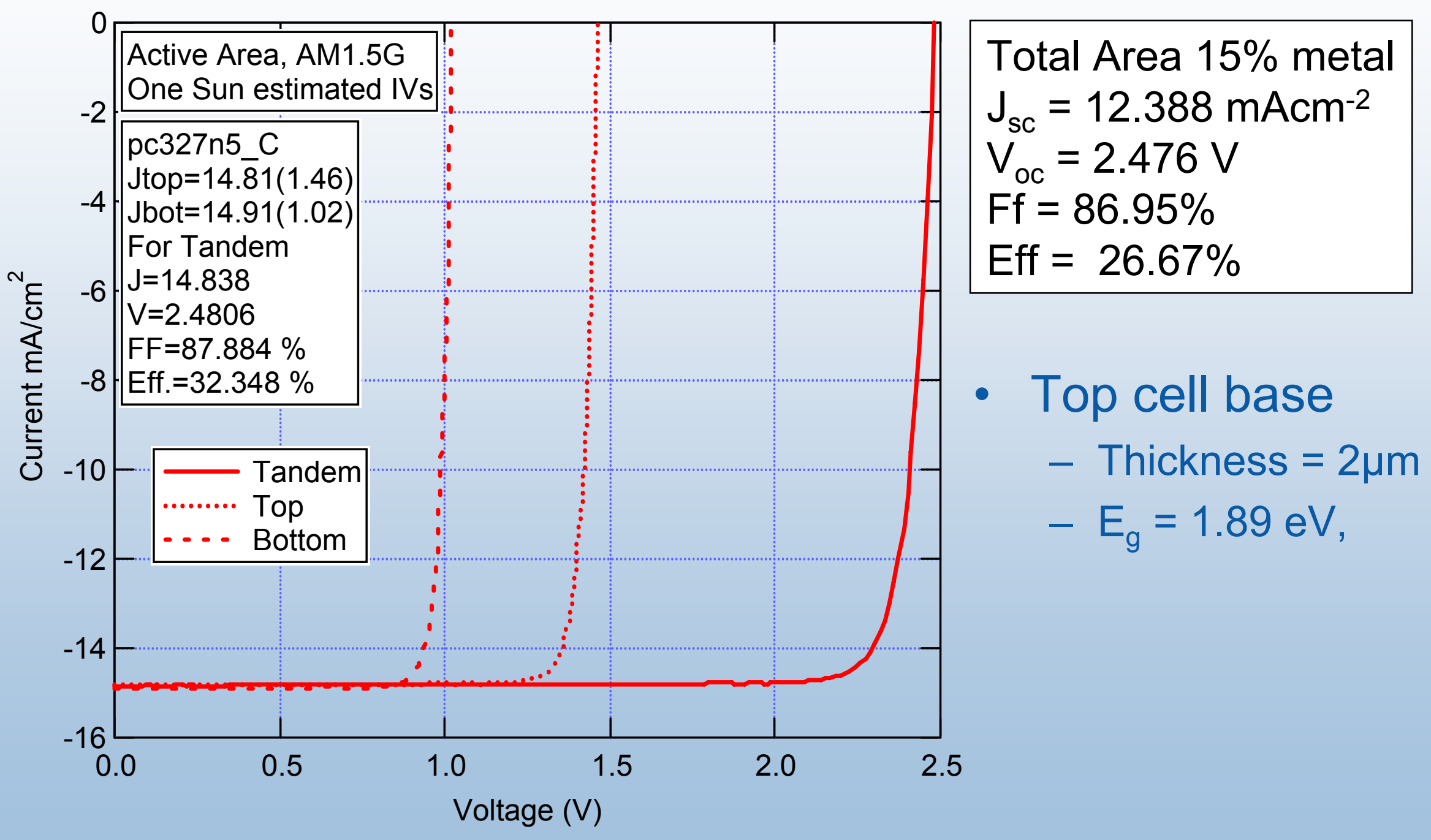




\section{Summary}

- $\mathrm{Sb}$ can be used to increase $\mathrm{V}_{\text {oc }}$ of a GalnP top cell.

- The photovoltaic quality of GalnP is relatively unaffected by the presence of $\mathrm{Sb}$.

- Sb-doped GalnP/GaAs tandem cells show promise for achieving efficiencies over $32 \%$. 


\section{Acknowledgements}

- Andrew Norman

- Jiang Chun-Sheng

- Michelle Young

- Alan Kibbler

- Bob Reedy

- Tom Moriarty 